place in the algorithm. The problem is that the proportion of urological and nephrological abnormalities found has varied greatly in different reports. In a large series Mariani et al found that, of 883 patients with haematuria in whom a diagnosis was made, 319 had important or life threatening conditions. ${ }^{1}$ Only 12 of these patients had renal disease that retrospectively had required renal biopsy. The ratio of risk to benefit and cost effectiveness were clearly less favourable for men and women below the age of 40 . The only group that was singled out because of an extremely low risk of finding any life threatening condition, however, was women below the age of 40 . In this group a different concept of evaluation may have to be applied.

Obviously, urologists, who are used to carrying out flexible cystoscopy, find renal biopsy much more threatening and difficult. Nephrologists may take the opposite view. The algorithm that I proposed in my editorial is by no means definitive; an algorithm can never cover all aspects of the management of a disease.

FRITZ H SCHRÖDER Professor

Department of Urology

Erasmus University,

3000 DR Rotterdam

The Netherlands

1 Mariani AJ, Mariani MC, Macchioni C, Stams UK, Hariharan A, Moriera A. The significance of adult hematuria: 1000 hematuria evaluations including a risk-benefit and cost-effectiveness analysis. $f$ Urol 1989;141:350-5.

\section{Exercise in pregnancy}

\section{Uncomplicated diabetes is not a contraindication}

EDrToR,-In her article on female athletes Roslyn Carbon lists diabetes mellitus among the contraindications to exercise in pregnancy. ${ }^{1}$ Although formal physical exercise is best avoided by pregnant women with complicated diabetes (proliferative retinopathy, nephropathy, and cardiovascular disease), there is no reason why those with uncomplicated diabetes should not continue to take regular physical exercise.

For women with insulin dependent diabetes with good diabetic control who perform regular blood glucose estimations with a glucose meter, the only danger is exercise induced hypoglycaemia, which may occur some time after completion of the exercise. This will call for an adjustment in carbohydrate intake. For women with non-insulin dependent diabetes the increased tissue sensitivity to insulin and the greater utilisation of glucose by muscle that is associated with exercise lead to lower glucose and free fatty acid concentrations and hence to more even diabetic control. ${ }^{2}$

MICHAEL BRUDENELL

Diabetic Pregnancy Unit,

King's College Hospital,

London SE5 9RS

1 Carbon R. Female athletes. BMF 1994;309:254-8. (23 July.)

2 Artal R, Wiswell RA, eds. Exercise in pregnancy. Baltimore:

Williams and Wilkins, 1986.

\section{Author's reply}

EDrToR,-I agree with Michael Brudenell that diabetic women should not unnecessarily be denied exercise. For the sake of brevity the list was not comprehensive and combined both absolute and relative contraindications, diabetes mellitus being a relative contraindication. Probably a better title for the list would have been "Conditions requiring specialist supervision."

ROSLYN CARBON The London Hospital Medical College, London E1 2AD

\section{GPs' awareness of surgical techniques}

EDITOR,-We agree with Grant Ingrams that communication and the willingness to share and discuss ideas are essential in the internal market. Our study showed that general practitioners are unaware of the advantages to patients of modern compared with outdated methods of cataract surgery. This procedure was simply used as a model, being in the top 10 of all surgical procedures. We made no judgment but reported the situation as it is.

All surgeons should be well informed about modern procedures, but, inevitably, some trail behind rather than keep up with the pack. Ingrams's assumption, however, that the solutions to most of the purchasing problems lie "with consultants and their professional bodies" is naive. The Royal College of Ophthalmologists produces guideline on clinical practice, and one on cataract is imminent.

As far as we are aware, the process of purchasing contracts is primarily administrative and rarely involves clinicians. Even if it does in certain areas, it is complex, and no single clinician could adequately comment on the full range of procedures under consideration in the average contract. The input of a number of clinicians would therefore be required to ensure that issues of quality are addressed. As Mark Davies and colleagues poin out, this would be time consuming and eat into clinical time. ${ }^{2}$

Unfortunately, the current focus on quality, including the much publicised "hospital sta ratings," seems to be primarily concerned with waiting times for patients and costs rather than clinical outcome. We must ensure that clinical outcome-a vital component-is brought into the purchasing process.

THEODOROS POTAMITIS Ophthalmology registra ALISTAIR FIEL DER Professor of ophthalmology

Birmingham and Midland Eye Hospital,

Birmingham B3 2NS

1 Ingrams G. GPs' awareness of surgical techniques. $B M f$ 1994;309:274. (23 July.)

2 Davies M, Logan J, Law J. GPs' awareness of surgical techniques. $B M \mp 1994 ; 309: 274-5$. (23 July.)

\section{Reflections on a genocide}

EDITOR,-John Hall graphically recorded the horror of Rwanda but reflected little on its cause. Like most of the British press he failed to look at the global problem. He could be compared with a reporter describing the horror of the bombing of Dresden by Britain without mentioning German military expansionism or the holocaust.

Although they comprise only $15 \%$ of the population Tutsis have ruled Rwanda and Burundi and the Hutus ( $85 \%$ of the population) for 300 years As in apartheid, if the Hutu kept to their inferior position the Tutsi could be benevolent and charming. Any attempt at equal opportunity, though, would be fiercely resisted. When working in Burundi we had two house girls-one from each tribe. They were friendly, but when they went to market the Hutu girl walked two paces behind the Tutsi girl and carried the shopping.

Thirty five years ago the Hutu majority seized power in Rwanda and threw off their subservien role. Hundreds of thousands of Tutsis fled to neighbouring countries, including Uganda. In Burundi, however, the Tutsi minority kept power and held on to it increasingly repressively. In 1972 fearful of a rebellion, this Tutsi governmen summarily executed 100000 educated Hutu, including schoolchildren as young as 12 (International Committee of Jurists estimate).

Is it surprising then that when the children of the
Rwandese Tutsi refugees in Uganda formed the Patriotic Front, invaded Rwanda, and tried to gain power (and have now succeeded) the Hutu majority was panic stricken? They could look forward only to the same servitude, repression, and bloodshed that the Hutu in Burundi had suffered. The Hutu saw the Tutsi who were still living in Rwanda, and naturally sympathetic to the invaders, as a dangerous third column.

Given the presence of a war, is it surprising that there were then massacres? If a right wing group invaded South Africa to reimpose apartheid who would be surprised if there were massacres of the white people there?

Why has there been no attempt in Britain generally, let alone the $B M F$, to understand the Hutu fears? Are British sympathies, too, naturally with the aristocratic English speaking invaders from Uganda rather than with the French speaking peasants from a previously almost unknown land?

R HUGH JAMES Consultant Anaesthetist Responsible for Audit

Leicester Royal Infirmary,

Leicester LE1 5WW

1 Hall P. Reflections on a genocide. $B M \mathcal{F}$ 1994;309:614-5. (3 September.)

\section{Plight of the Kurdish people}

EdrToR,-C M Milroy's Personal View was too familiar to doctors like me who grew up in Iraqi Kurdistan under the regime of Saddam Hussein. ${ }^{1}$

In 1983 around 8000 Barzani men and women were arrested in the resettlement of Qushtapa near Erbil, the capital of Iraqi Kurdistan. To date their fate is still unknown, but most people believe that they are dead. Although there was an international outcry after Saddam's use of chemical weapons against Kurdish civilians in Halabja in 1988, the Baghdad regime had attacked the valley of Balistan near Erbil with chemical weapons for the first time in March 1987. It marked the beginning of a new campaign by the Iraqi regime to wipe out Kurdish rural life. The campaign was later code named ANFAL. Three hundred victims of those first gas attacks sought treatment at Erbil Hospital. They were transferred to the local military hospital, where they were taken prisoners, denied treatment, and left to die; in some cases survivors were shot.

At the end of the Iran-Iraq war in July 1988 the ANFAL operations escalated to a degree suggestive of genocide of the Kurdish people by the Iraqi regime. Villages were first bombarded by aircraft using chemical weapons. Villagers who escaped were captured, and the entire village was razed with bulldozers to the ground. Finally, the survivors were taken to unknown places in different parts of Iraq, where they were executed collectively in prearranged pits, which became mass graves. Thousands of villages were destroyed, and the number of missing people is now estimated to be at least 100000 . Some of these mass graves were discovered after the collapse of Sadam's rule in Kurdistan after the Gulf war.

The documents, secret files, and audiovisual material found at the headquarters of the Iraqi secret police in Kurdistan show to some degree the extent of the terror. The Baghdad regime seems to have kept individual files on a large part of the Kurdish population about affiliations to opposition parties, personal weaknesses, and family political loyalties. Punishment for offences extended to the whole family. There were boxes and boxes of files on people's lives, the information having been extracted under the most brutal forms of torture. A vast bulk of files remains that has not yet been examined. In the late 1980 s the secret police videoed public executions for public distribution to extend the rule of terror.

The documents show that the whole population was under investigation. Four and a half million 